\title{
Compounding Health Risks and Increased Vulnerability to SARS-CoV-2 for Racial and Ethnic Minorities and Low Socioeconomic Status Individuals in the United States
}

\author{
Elise M. Myers ${ }^{1}$ \\ e.myers@columbia.edu \\ ${ }^{1}$ Columbia University; $535 \mathrm{~W} 116^{\text {th }}$ Street, New York, NY 10027
}

\begin{abstract}
Recent clinical SARS-CoV-2 studies link diabetes, cardiovascular disease, and hypertension to increased disease severity. In the US, racial and ethnic minorities and low socioeconomic status (SES) individuals are more likely to have increased rates of these comorbidities, lower baseline health, limited access to care, increased perceived discrimination, and limited resources, all of which increase their vulnerability to severe disease and poor health outcomes from SARS-CoV2. Previous studies demonstrated the disproportionate impact of pandemic and seasonal influenza on these populations, due to these risk factors. This paper reviews increased health risks and documented health disparities of racial and ethnic minorities and low SES individuals in the US. Pandemic response must prioritize these marginalized communities to minimize the negative, disproportionate impacts of SARS-CoV-2 on them and manage spread throughout the entire population. This paper concludes with recommendations applicable to healthcare facilities and public officials at various government levels.
\end{abstract}

Keywords: Coronavirus, COVID-19, comorbidity, race and ethnicity, health disparities

\section{Introduction}

The novel human coronavirus, severe acute respiratory syndrome coronavirus (SARS-CoV-2 or COVID-19), was declared a pandemic by the WHO on March $11,2020^{1}$. Since the January $15^{\text {th }}$ arrival of the first documented case in the United States, the disease has been rapidly spreading through the country, reaching every state and the District of Columbia (DC) by March $17^{\text {th }}$. As of April 8, 2020, there have been 554,849 confirmed cases and 21,942 deaths nationwide, with every state, DC, and 4 of 8 territories reporting cases $^{2}$.

Rising wealth inequality ${ }^{3}$ and persistent social disparities experienced by racial and ethnic minorities in the $\mathrm{US}^{4}$ lead to significant vulnerability of racial and ethnic minorities and low socioeconomic status (SES) individuals to pandemic events ${ }^{5}$. Already, there have been reports of disproportionate prevalence and severity of SARS-CoV-2 cases among Blacks, ${ }^{6,7,8,9}$, and American Indians ${ }^{10 *}$. Previous research has highlighted the disproportionate impact of the H1N1 Influenza A pandemic ${ }^{11,12,13,14,15}$ and seasonal influenza ${ }^{16,17,18}$ on both racial and ethnic minorities and low SES individuals.

Existing disparities for racial and ethnic minorities and low SES individuals in the US, combined with evidence of disproportionate impacts of influenza, suggest that SARS-CoV-2 will have a devastating impact on these vulnerable populations. This articles reviews: 1) recent findings related to comorbidities and SARS-CoV-2 case severity, 2) disparities in health and healthcare 
for racial and ethnic minorities in the US, 3) health risks associated with lower SES, and 4) compounding risk at the intersection of low SES and racial and ethnic minority identity. To conclude, recommendations for minimizing the impact of the SARS-CoV-2 pandemic on vulnerable populations are provided for both inside healthcare facilities and at various community organization and government levels.

\section{SARS-CoV-2 Risks for Patients with Comorbidities}

From recently available data on patients from the early stages of the outbreak of SARS-CoV-2 in China, it is increasingly apparent that, in addition to older patients ${ }^{19}$, patients with comorbidities have a higher likelihood of severe disease and an increased risk of death ${ }^{20}$. Recent studies report a range of 40-63\% of severely or critically ill hospitalized patients have comorbidities ${ }^{19,20,21,22,23}$, similar to ranges reported for Middle East Respiratory Syndrome coronavirus (MERS-CoV) ${ }^{24}$. Further, patients with severe disease are more likely to have a co-existing illness than patients with non-severe disease ${ }^{25}$.

The most common comorbidities reported in these early studies are hypertension, diabetes mellitus, and cardiovascular disease ${ }^{19,21,25,26}$, all of which have been correlated to increased mortality risk ${ }^{19}$ and severe disease ${ }^{25}$ in SARS-CoV-2 patients. Pre-existing cardiovascular disease and diabetes previously have been linked to acute cardiac events and poor health outcomes for patients with influenza and respiratory infections ${ }^{27,28,29,30,31}$. One hypothesis for increased SARS-CoV-2 severity with hypertension and diabetes is that both conditions can be treated with angiotensin-converting enzyme (ACE) inhibitors and angiotensin II type-I receptor blockers (ARBs), which increase the expression of ACE2 ${ }^{32,33}$. Because human pathogenic coronaviruses bind to target cells via ACE 2, treatment of hypertension and diabetes with ACE inhibitors and ARBs could facilitate SARS-CoV-2 infection and increase disease severity ${ }^{34}$. Alternative treatments for patients with hypertension and diabetes that do not increase ACE 2 expression may be important to implement ${ }^{34}$. In addition, individual-specific treatment plans to address serious comorbidities alongside pneumonia have been recommended ${ }^{23}$.

Chronic lung or respiratory system disease ${ }^{19,21,26}$, cerebrovascular disease ${ }^{21,25}$, chronic kidney disease $^{19}$ and a history of smoking ${ }^{21}$ are other comorbidities reported in patients with more severe cases of SARS-CoV-2. Of these comorbidities, chronic lung disease and chronic kidney disease significantly correlate with increased mortality risk ${ }^{19}$. Notably missing from studies is concrete information on the effect of asthma on SARS-CoV-2 severity, which has been attributed to the low prevalence in the general population in $\mathrm{China}^{26}$. Generally, the presence of any comorbidity increased the risk of severe illness and mortality for SARS-CoV-2 hospitalized patients $^{20,25,26}$. In one study, $23 \%$ of SARS-CoV-2 critically ill patients had aggravated disease that was attributed to their original comorbidity ${ }^{23}$. Previous work demonstrated that diabetes, hypertension, obesity, and cardiovascular disease correlate with case severity of other coronaviruses, including MERS-CoV ${ }^{24}$ and influenza illness ${ }^{35,36}$. Recent studies have also demonstrated that SARS-CoV-2 infections can cause damage to various organs (i.e. heart, liver, and kidneys) and organ systems (i.e. blood and immune) $)^{21,37}$. Damage to organs and organ systems that are already compromised by comorbidities likely contributes to the complication of organ system and organ failure ${ }^{19-22}$. 
It is important to note that data from hospitalized patients does not reflect the total disease burden of the general population, in which an estimated $80 \%$ of total SARS-CoV-2 cases are likely mild ${ }^{38}$ and do not require hospitalization. However, data on hospitalized patients provides insight into which subpopulations are more vulnerable to severe disease and higher mortality risk.

\section{Elevated Risk for Severe SARS-CoV-2 for Racial and Ethnic Minorities in the United States}

\section{Elevated Risks for Seasonal Influenza, Pneumonia, and Respiratory Infections}

Disparities in morbidity and mortality for racial and ethnic groups have been previously identified in respiratory diseases, including pneumonia and seasonal influenza ${ }^{39,40,41}$. The US has a long history of health disparities for seasonal and pandemic influenza, with higher mortality rates for Black vs. non-Hispanic white (NHW) populations reported from the 1918-1919 influenza pandemic ${ }^{42,43}$ through to modern day ${ }^{5,16,44}$. Hospitalization rates for Black and Hispanic children are higher than those of NHWs for respiratory syncytial virus, seasonal influenza, and parainfluenza viruses ${ }^{17}$. Further, rates of respiratory viral infections are higher for Apache Indians, Alaska Natives and Blacks than for $\mathrm{NHWs}^{45}$. These aforementioned differences align with the larger trend that influenza-associated pneumonia and pandemic influenza-related deaths are more common in racial and ethnic minority populations $16,40,46,47$.

The increased risks to racial and ethnic minorities in the United State in the current SARS-CoV2 pandemic are similar to those highlighted during the $2009 \mathrm{H} 1 \mathrm{~N} 1$ novel influenza A pandemic. An estimated 60.8 million cases of H1N1 with 274,304 hospitalizations and 12,469 deaths occurred in the US from April 2009 to April 2010 ${ }^{48}$. The current SARS-CoV-2 pandemic has caused more deaths in the US in under 3 months (21,942 deaths as of April 13, 2020²), demonstrating the increased severity of the current pandemic and underlining the need to examine and apply past lessons to protect vulnerable populations.

Severe cases of H1N1 in the United States were found to disproportionately impact racial and ethnic minorities, as noted through age-adjusted hospitalization rates and deaths ${ }^{11,12,49}$. Hospitalizations related to H1N1 were most common for American Indians and Alaska Natives $^{12}$, though Hispanics and Blacks also were hospitalized at higher rates than NHWs ${ }^{12,49}$. In fact, American Indians were 2.6 times more likely to be hospitalized than NHWs ${ }^{13}$, while Alaska Native and Asian/Pacific Islanders were 2-4 times likely to be hospitalized than NHWs during the H1N1 pandemic ${ }^{14}$. Overall, severe disease and death from H1N1 was 4 times higher for American Indians and Alaska Natives than for all other racial and ethnic groups combined ${ }^{11}$. This trend of increased hospitalization of indigenous populations relative to the general population was also true in Canada, New Zealand, and Australia ${ }^{50,51,52}$. As related to their proportion of the general population, pediatric deaths due to H1N1 in the United States were notably high for Hispanics and Asian/Pacific Islanders and lower than expected among NHWs ${ }^{12}$. Suggested causes for the disproportionate effect of H1N1 on racial and ethnic minorities include higher rates of comorbidities, lower baseline health, increased environmental exposure, lower vaccination rates, increased poverty, and reduced access to quality care ${ }^{12,13,15,31,51}$.

\section{Prevalence of SARS-CoV-2 Relevant Comorbidities}


Disparities in outcomes for racial and ethnic minorities have partially been attributed to higher prevalence of underlying health conditions (i.e. comorbidities) ${ }^{11}$, some of which have now been linked to more severe SARS-CoV-2 illness, like diabetes, cardiovascular disease, and hypertension. Rates of diabetes in the US are high, with CDC projections that about $40 \%$ of US adults will develop diabetes during their lifetime ${ }^{53}$. The prevalence of diabetes among adult American Indians or Alaska Natives, Blacks, Hispanics, and Asian Americans is higher than that of NHWs s4,55,56,57 with many of these issues concentrated in the southern, Appalachian region of the US ${ }^{53}$. National reported rates of diabetes are even higher for American Indians or Alaska Natives ${ }^{53-55}$. Higher rates of diabetes in American Indians were linked to increased severity of H1N1 cases ${ }^{58}$. While rates of diabetes for Asian-Americans are only slightly higher than those of NHWs, diabetes prevalence is much higher for the Native Hawaiian and other Pacific Island (NHOPI) subgroup ${ }^{59,60,61}$. Higher rates of diabetes among racial and ethnic minorities is linked to their commonly lower SES. In previous research, elevated rates of Type II diabetes have been found in neighborhoods, across racial and ethnic groups, that have poorer resources for physical activity and healthy foods ${ }^{62}$.

Cardiovascular disease, hypertension, and more severe related outcomes have also been reported as more common among US ethnic minorities ${ }^{63,64}$, though cardiovascular disease affects ethnic groups differently. For Blacks, cardiovascular disease rates are slightly lower than those of NHWs for males, but are much higher for females ${ }^{65}$. Regardless of prevalence, Blacks have higher hospitalization rates and greater risk of death due to cardiovascular disease than $\mathrm{NHWs}^{65,66,67}$. Specifically for hypertension, Blacks have higher rates across every age category than all other commonly measured racial groups ${ }^{68}$. The increased burden of hypertension and heart failure on Black populations occurs earlier compared to $\mathrm{NHWs}^{69,70}$, suggesting that the commonly cited age predictor of risk for SARS-CoV-2 $2^{71}$ may not apply equally across racial groups $^{70}$. High rates of hypertension are also well-documented for indigenous US populations, as compared to the general population ${ }^{72,73}$. When separated from the larger Asian racial category, it is apparent that NHOPI are one of the highest risk populations for cardiovascular and cardiometabolic diseases ${ }^{59}$. NHOPI women experience higher frequency of hypertension and high cholesterol than NHWs and other ethnic groups ${ }^{74,75}$, while incidence of hypertension is highest in Native Hawaiians ${ }^{73,76,77}$. Further, mortality of Native Hawaiians due to cardiovascular disease occurs an average of 7.5 years earlier than other ethnic groups. In contrast, studies have found that the US Hispanic population is less likely to have cardiovascular disease and suffer severe outcomes than NHWs ${ }^{65,78}$, though the prevalence of risk factors described in other studies $^{79}$ suggests an incomplete picture of Hispanic cardiovascular disease ${ }^{78}$. Further racial diversity within the Hispanic population must be considered ${ }^{80}$. For example, previous studies have suggested that Hispanics of Caribbean descent have similar hypertension and cardiac hypertrophy as Blacks ${ }^{78,81}$.

While there is currently insufficient data to determine if asthma is a compounding risk factor for SARS-CoV-2, asthma is well known to increase the severity of seasonal and pandemic influenza ${ }^{82}$. Asthmatic children with influenza consistently have higher rates of hospitalizations, outpatient visits, and antibiotic courses than children without asthma ${ }^{83,84}$. During the H1N1 pandemic influenza, rates of intensive care admission, hospitalization, and pneumonia diagnoses for asthmatic children were even higher ${ }^{82}$. In the US, approximately $8 \%$ of adults and children have asthma, with higher than average prevalence for Blacks (10.7\%); American Indians, Alaska 
Natives and Native Hawaiians (10.4\%); and Puerto Ricans $(14 \%)^{85}$. Some arguments for disparities in asthma prevalence include lower SES, poorer home environmental conditions, and disparate social stressors ${ }^{86}$. Based on the past trends of increased morbidity and mortality of asthmatics from seasonal and pandemic influenza, asthma is likely a comorbidity of concern for SARS-CoV-2.

\section{Influence of Systemic Racism on Baseline Health}

Systemic racism experienced by racial and ethnic minorities in the US has been found to exacerbate comorbidities, influence medical care, and create pervasive differences in wealth. Overall, social conditions are considered fundamental causes of disease, as access to resources is well documented to allow for avoiding risk and minimizing disease consequences ${ }^{87}$. Limited access to information, good jobs without toxic exposure, health benefits, healthy foods, and wellsupported, safe living options all combine to produce inequality in disease prevalence and health risk factors. Further, intentionally placed hazardous sites near communities of color and lower income communities result in increased pollution exposure ${ }^{88}$, which has been linked to prevalence of health risk factors, like hypertension ${ }^{89}$.

Perceived discrimination and experienced racism have been linked to higher incidence of diabetes, cardiovascular disease, hypertension, and respiratory problems ${ }^{90}$, all of which could compound disease from SARS-CoV-2. Further, recurrent experiences of discrimination generate negative, stress-related physiological and psychological responses, which can significantly impact health ${ }^{91,92}$, like by increasing the risk for heart disease, diabetes, and infection, as seen in Blacks ${ }^{93}$. Exposure to social stressors and environmental adversity, which has been linked to elevated risk of cardiovascular disease and other comorbidities for Blacks ${ }^{94}$, creates higher allostatic loading (or "weathering") for Blacks than NHWs, even when adjusting for SES" .

Perception of racism by Black patients also decreases healthcare trust ${ }^{96,97}$, which can decrease the efficacy of provided care or patient-implementation of preventative treatment ${ }^{98,99}$. And this perception is supported by findings that the majority of non-Blacks in the US exhibit implicit biases against Blacks ${ }^{100}$. Knowledge of historical racism in medicine, particularly forced and/or risky experimentation and medical trials ${ }^{101,102}$, may also contribute to patient distrust of modern medical practitioners, creating an additional barrier to care. Negative effects of discrimination on health have been more extensively studied in the US for Black Americans, but are reported for other racial and ethnic minority groups ${ }^{91,103,104}$. For example, more perceived racism has been correlated with self-reported hypertension in Native Hawaiians ${ }^{105}$. Centuries of discrimination, disenfranchisement, and perceived second-class status of indigenous populations in their own homeland due to colonial legacies ${ }^{106,107,108}$, have been linked to poor health outcomes ${ }^{109,110,111}$. Further, for American Indians, microaggressive experiences with their healthcare providers correlate with self-reported heart attack history ${ }^{112}$. It is worth noting that elevated stress due to discrimination for immigrants has been correlated with lower health baselines ${ }^{113,114}$ and is likely compounded by stressors of immigration status or acculturation. Finally, in addition to perceived discrimination, systemic effects of racism like neglect and disinvestment in segregated communities increases community exposure to environmental toxins ${ }^{115}$, which can influence cardiovascular disease ${ }^{116}$, incidence of diabetes ${ }^{62}$, hypertension $^{117}$, and respiratory health ${ }^{118}$.

\section{Racism and Discrimination in Medical Care}


Documented disparities in medical care for racial and ethnic minorities are critical to consider when facing a national medical crisis, like SARS-CoV-2. In recent years, healthcare disparities for Black Americans (as compared to NHWs) have been more prominently highlighted, such as higher maternal mortality rates ${ }^{119}$, decreased likelihood of children to receive antibiotics ${ }^{120}$, decreased likelihood of finger re-attachment for children ${ }^{121}$, and increased use of limb amputation to treat lower extremity ischemia (restriction in blood supply) ${ }^{122}$. In pneumoniarelated hospitalizations, Blacks and other minorities have been observed to be $70-80 \%$ less likely to receive antimicrobial agents within 8 hours of arrival at a hospital than NHWs ${ }^{123}$. Early identification and timely treatment of critical cases of SARS-CoV-2 is vital for reducing disease severity and preventing spread ${ }^{21}$, so biases in care could have significant consequences. It is important to note that the literature is divided upon whether or not implicit biases of clinicians translate to different treatment recommendations or care ${ }^{124,125,126}$, though existing studies generally confirm an implicit preference for NHWs over Blacks ${ }^{127,128,129}$. Efforts to treat without acknowledging race or ethnicity (i.e. colorblindness ${ }^{130}$ ) or individual-level education to combat bias ${ }^{131}$ have limited positive impact, so the recommendation is commonly individualized, patient-centered care ${ }^{132}$. In a pandemic situation where clinicians are overburdened, a more effective strategy may be regular reminders to clinicians of the existence of racial and ethnicity implicit biases ${ }^{133}$ and, where possible, oversight of treatment practices.

\section{Socioeconomic Status (SES) as a Health Risk Factor}

Low socioeconomic status (SES) is a universal risk factor for disease in the US ${ }^{134,135}$ and exacerbates health outcomes for racial and ethnic minorities. Generally, health inequalities in the US improve with income or education level ${ }^{136,137}$, which is partially attributed to healthcare access $^{5}$. Rising wealth inequality in the US ${ }^{3}$ expands existing health disparities by limiting access to resources to avoid health risks or minimize disease impacts ${ }^{87}$. Lower SES individuals are more likely to be admitted to the hospital for short-term complications of diabetes, hypertension, congestive heart failure, and asthma ${ }^{138}$, all comorbidities of concern for SARS-CoV-2. Significant decreases in the number of hospitals serving rural, low income populations ${ }^{139}$ has reduced access to care. The intensity of treatment needed for patients during the H1N1 pandemic (e.g. mechanical ventilation) was significantly associated with a lack of or delayed antiviral treatment ${ }^{13}$, underscoring the importance of improving access to care for low SES individuals during the SARS-CoV-2 pandemic. In addition to access difficulties, lower income individuals have also reported perceived discrimination ${ }^{140}$ which, as previously mentioned, increases stress and decreases baseline health.

Positive feedback loops between disease burden and poverty, as seen in simple combined economic and host-pathogen system models, demonstrate the increased risk of poor health for low income individuals both during and after the SARS-CoV-2 pandemic. Lower SES individuals have greater exposure risk, as they are more likely to use public transportation ${ }^{141}$ and may work in essential jobs that continue amid social distancing measures ${ }^{142}$. Jobs common for lower SES individuals (e.g. service industry) have fewer labor protections, like paid sick leave ${ }^{143,144}$, and are more likely to terminate during a quarantine, thus limiting the ability to stockpile food and water. Ensured job security or income replacement would limit the negative effects of quarantine measures on already vulnerable populations and, thereby, encourage quarantine compliance ${ }^{145}$. Further, in the US, where health insurance is commonly tied to employment $^{146}$, job loss can mean health insurance loss and limited healthcare access. It must be 
noted that, in SARS-CoV-2 studies published from China, treatment costs were covered by medical insurance ${ }^{21}$. Outcomes may be very different in the US due to high treatment costs that could particularly devastate lower income individuals.

Hospitalizations in the US among children and adults for seasonal influenza and 2009 H1N1 were found to increase with poverty ${ }^{13,15,18,147}$. A model of influenza spread that incorporated increasing susceptibility with decreasing SES closely matched the increased early influenza rate in high-poverty census tracts observed during the $2009 \mathrm{H} 1 \mathrm{~N} 1$ pandemic ${ }^{148}$. Modeled influenza spread in Delhi demonstrated that, by ignoring the attributes of slums (lower income, crowding, etc.) and their $20 \%$ higher infection rate, risk is underestimated, leading to underestimation of infections in the larger population ${ }^{149}$. Current predictions for the spread of SARS-CoV-2 in the US should include disparities due to low income and SES to more accurately predict disease burden for more vulnerable communities.

\section{The Intersection of Socioeconomic Status, Race, and Ethnicity}

The effects of low SES on health are compounded for racial and ethnic minorities ${ }^{150,151,152,153,154}$. Blacks and Hispanics in the US are reported to have poverty levels 2-3 times higher than those of NHWs $^{155}$. While the broad Asian category is often reported to have a comparable level of poverty to the NHW population, Asian subpopulations like Hmong, Laotian, and Cambodian groups have income levels similar to Black and American Indian populations ${ }^{156}$. Some studies demonstrated reduced race- and ethnicity-related health disparities when controlling for $\mathrm{SES}^{157,158}$, but racial and ethnic minorities (especially Blacks) often still have significantly higher risk of poor health ${ }^{159,160}$ and environmental hazard exposure ${ }^{88}$, even across high income levels ${ }^{161}$.

Lower access to preventative healthcare for racial and ethnic minorities as compared to NHWs ${ }^{12}$, is inferred from lower vaccination rates and later stage cancer diagnoses ${ }^{162,163}$. Higher density, racially-segregated communities with more limited resources also have diminished access to care $^{115,164}$, though lower mortality has occasionally been linked to high density Mexican- and Cuban-American neighborhoods ${ }^{165}$. In contrast, rural location, combined with low SES, limits healthcare access (i.e. low utilization rates) for US indigenous communities ${ }^{166}$. Difficulties in accessing care are also reported by NHOPI, who are overrepresented in lower SES levels ${ }^{167}$. Low SES racial and ethnic minority communities may also have limited English proficiency and require translator services ${ }^{5}$, which are likely be limited during a pandemic. In the H1N1 pandemic, disparities in access to care, in conjunction with low vaccination rates and higher underlying chronic disease, increased disease severity and susceptibility to complications for racial and ethnic minorities ${ }^{168}$.

\section{Protecting Vulnerable Communities in SARS-CoV-2 Response}

It has been previously shown when methods are implemented to prevent and treat disease, health disparities related to SES and racial and ethnic groups increase ${ }^{169}$. Deliberate care must be taken to enact policy changes both inside healthcare facilities and at all government levels to ensure SARS-CoV-2 prevention and treatment does not neglect or exacerbate existing disparities in social conditions and health risks of vulnerable communities ${ }^{87,157,169}$. Though this paper specifically addresses the US, health disparities are globally pervasive. Efforts to protect vulnerable populations in all nations during this pandemic will be critical for managing the spread and effects of SARS-CoV-2 throughout the entire population. 
While this paper does not explicitly address disability status or LGBTQ identity, both should be noted as factors that can increase vulnerability. Particularly in rural areas where critical services are more expensive and less specialized ${ }^{170,171}$, individuals with disability will likely experience greater difficulties in accessing basic necessities (food, water, etc.) and attaining care. Further, individuals with mental and physical disabilities in the US have reported perceived discrimination in healthcare ${ }^{140,172}$ and additional barriers in communication, accessing local services, and service eligibility ${ }^{173,174,175}$. Individuals with disability status are also likely to have low SES ${ }^{137,176}$ and other secondary health conditions ${ }^{177}$. Perceived discrimination when accessing health services has also been reported by LGBTQ individuals ${ }^{178}$. LGBTQ individuals are more likely to have lower SES, disability status, and poor physical health conditions ${ }^{179,180,181}$ and face structural barriers to accessing care ${ }^{182,183}$. And, as for SES, discrimination related to healthcare for both disability status and LGBTQ identity is more likely for racial and ethnic minorities ${ }^{140,178}$.

The following recommendations have been inspired by the many public health experts and scholars cited in this article. Decision-makers and stakeholders are also encouraged to read additional sources with thorough reviews on risks for vulnerable populations and concrete recommendations ${ }^{5,142,184}$.

\section{Recommendations}

For Hospital Administrators, Health Practitioners, and Infectious Disease Specialists

- Treatments for SARS-CoV-2 patients with comorbidities, like diabetes and hypertension, should be individualized to prevent worsening of the initial comorbidity and the overall health of the patients. Consider incorporating treatments for initial comorbidities that do not increase the expression of ACE2.

- In healthcare facilities, practitioners should be reminded of implicit bias in medical care and its potential negative impact on patient outcomes, particularly for racial and ethnic minorities, LGBTQ individuals, and people with disabilities. When possible, oversight of emergency care can be incorporated to ensure consistent care, even as practitioners become overwhelmed with the SARS-CoV-2 caseload.

- Collect extensive data on treatments and outcomes. Aggregate the data for regular analysis of possible disparities in severity of cases and poor outcomes for racial and ethnic minorities and low SES individuals. Real-time discoveries of disparities can inform shifts in care in hospitals and changes in communication or resource distribution outside the hospitals. Results should be communicated in a timely manner to the public, as is being done in Illinois, Michigan, and North Carolina.

- Incorporate the increased risk factors for racial and ethnic minorities and low SES individuals in predictive models of SARS-Cov-2 spread to improve accuracy and highlight high risk regions of disease and disease disparity.

For Public Officials, Public Health Strategists, and Community Leaders

- Public health warnings and vulnerability classifications for SARS-CoV-2 should reflect the higher comorbidities and increased risks for racial and ethnic minorities and low SES individuals. Emphasize the increased risk of severe cases to these populations. Additional 
emphasis should be made to these populations of their increased risk of more severe cases of SARS-CoV-2

- Social policies should be put in place to minimize economic burdens (e.g. rent/mortgage, bill, and student loan freezes and/or forgiveness, health insurance (universal healthcare, public option or premiums paid), income replacement, encouragement to employers to commit to rehire individuals post-pandemic, etc.), which will improve compliance with quarantine.

- Invest funding heavily in community healthcare systems that serve racial and ethnic minorities and low SES individuals, where the need will be greatest.

- Increase accessibility of testing for vulnerable communities (including remote testing), considering the various barriers to access they may face (e.g. public transportation reliance).

- When a vaccine is released, plan for distribution through a variety of venues like private pharmacies, doctor's offices, mobile community health centers, soup kitchens, and transit points to increase accessibility of the vaccine and limit crowding at hospitals and clinics.

- Increase access to primary care (facilities or remote) for low SES and racial and ethnic minority individuals, who are more likely to rely on hospitals for primary care than NonHispanic white counterparts, to minimize hospital transmission of SARS-CoV-2.

- Communicate health risks, recommendations, and current status of the pandemic in relevant, practical, and tailored ways with vulnerable populations. Demonstrate a clear commitment to their well-being to build trust. Ensure that information is available in multiple languages and is disseminated over various relevant platforms for maximum reach. Engage community leaders, local service providers, and activists for these vulnerable subpopulations in communication efforts to both share information and gather concerns and feedback that can inform evolving pandemic mitigation efforts.

\section{Acknowledgement}

The author would like to thank Dominic T. Walker and Tiffany J. Huang for their feedback on early drafts. This work was supported by the NASA grant award 80NSSC19K1370, which funds the salary of the author.

The author declares no conflict of interest.

*For context, in this article, the racial definition Black is used for literature referring to NonHispanic Blacks and African-Americans living in the United States. The term American Indian is used to refer to indigenous people in the continental United States.

\footnotetext{
${ }^{1}$ World Health Organization. WHO Director-General's opening remarks at the media briefing on COVID-19 - 11 March 2020. World Health Organization 2020. https://www.who.int/dg/speeches/detail/who-director-general-s-opening-remarks-at-the-mediabriefing-on-covid-19---11-march-2020 (accessed April 1, 2020).

${ }^{2}$ Centers for Disease Control and Prevention. Cases in U.S. Centers for Disease Control and Prevention 2020. http://www.cdc.gov/coronavirus/2019-ncov/cases-updates/cases-in-us.html (accessed April 13, 2020).
} 
${ }^{3}$ Saez E, Zucman G. Wealth inequality in the United States since 1913: Evidence from capitalized income tax data. The Quarterly Journal of Economics. 2016 May 1;131(2):519-78. ${ }^{4}$ Singh GK, Daus GP, Allender M, Ramey CT, Martin EK, Perry C, De Los Reyes AA, Vedamuthu IP. Social determinants of health in the United States: addressing major health inequality trends for the nation, 1935-2016. International Journal of MCH and AIDS. 2017;6(2):139.

${ }^{5}$ Hutchins SS, Fiscella K, Levine RS, Ompad DC, McDonald M. Protection of racial/ethnic minority populations during an influenza pandemic. American journal of public health. 2009 Oct;99(S2):S261-70.

${ }^{6}$ Johnson A, Buford T. Early Data Shows African Americans Have Contracted and Died of Coronavirus at an Alarming Rate. ProPublica 2020. http://www.propublica.org/article/early-datashows-african-americans-have-contracted-and-died-of-coronavirus-at-an-alarming-rate (accessed April 6, 2020).

${ }^{7}$ Illinois Department of Public Health. COVID-19 Statistics. COVID-19 Statistics | IDPH 2020. http://www.dph.illinois.gov/covid19/covid19-statistics (accessed April 6, 2020).

${ }^{8}$ Michigan.gov. Coronavirus Michigan Data. Coronavirus - Michigan Data 2020. http://www.michigan.gov/coronavirus/0,9753,7-406-98163_98173---,00.html (accessed April 6, 2020).

${ }^{9}$ NC Department of Health and Human Services. COVID-19 North Carolina Dashboard. NCDHHS 2020. http://www.ncdhhs.gov/divisions/public-health/covid19/covid-19-nc-casecount\#by-race/ethnicity (accessed April 6, 2020).

${ }^{10}$ Lee K. No running water. No electricity. On Navajo Nation, coronavirus creates worry and confusion as cases surge. Los Angeles Times 2020. http://www.latimes.com/worldnation/story/2020-03-29/no-running-water-no-electricity-in-navajo-nation-coronavirus-createsworry-and-confusion-as-cases-surge (accessed April 6, 2020).

${ }^{11}$ Centers for Disease Control and Prevention (CDC). Deaths related to 2009 pandemic influenza A (H1N1) among American Indian/Alaska Natives - 12 states, 2009. MMWR Morbidity and Mortality Weekly Report 2009. https://www.ncbi.nlm.nih.gov/pubmed/20010508.

${ }^{12}$ Dee DL, Bensyl DM, Gindler J, Truman BI, Allen BG, D’Mello T, Pérez A, Kamimoto L, Biggerstaff M, Blanton L, Fowlkes A. Racial and ethnic disparities in hospitalizations and deaths associated with 2009 pandemic influenza A (H1N1) virus infections in the United States. Annals of epidemiology. 2011 Aug 1;21(8):623-30.

${ }^{13}$ Thompson DL, Jungk J, Hancock E, Smelser C, Landen M, Nichols M, Selvage D, Baumbach J, Sewell M. Risk factors for 2009 pandemic influenza A (H1N1)-related hospitalization and death among racial/ethnic groups in New Mexico. American journal of public health. 2011 Sep;101(9):1776-84.

${ }^{14}$ Wenger JD, Castrodale LJ, Bruden DL, Keck JW, Zulz T, Bruce MG, Fearey DA, McLaughlin J, Hurlburt D, Hummel KB, Kitka S. 2009 Pandemic influenza A H1N1 in Alaska: temporal and geographic characteristics of spread and increased risk of hospitalization among Alaska Native and Asian/Pacific Islander people. Clinical infectious diseases. 2011 Jan 1;52(suppl_1):S189-97. ${ }^{15}$ Yousey-Hindes KM, Hadler JL. Neighborhood socioeconomic status and influenza hospitalizations among children: New Haven County, Connecticut, 2003-2010. American journal of public health. 2011 Sep;101(9):1785-9.

${ }^{16}$ Byrd WM, Clayton LA. An American health dilemma: Race, medicine, and health care in the United States 1900-2000. Routledge; 2001 Dec 21. 
${ }^{17}$ Iwane MK, Edwards KM, Szilagyi PG, Walker FJ, Griffin MR, Weinberg GA, Coulen C, Poehling KA, Shone LP, Balter S, Hall CB. Population-based surveillance for hospitalizations associated with respiratory syncytial virus, influenza virus, and parainfluenza viruses among young children. Pediatrics. 2004 Jun 1;113(6):1758-64.

${ }^{18}$ Tam K, Yousey-Hindes K, Hadler JL. Influenza-related hospitalization of adults associated with low census tract socioeconomic status and female sex in New Haven County, Connecticut, 2007-2011. Influenza and other respiratory viruses. 2014 May;8(3):274-81.

${ }^{19}$ Zhou F, Yu T, Du R, Fan G, Liu Y, Liu Z, Xiang J, Wang Y, Song B, Gu X, Guan L. Clinical course and risk factors for mortality of adult inpatients with COVID-19 in Wuhan, China: a retrospective cohort study. The Lancet. 2020 Mar 11.

${ }^{20}$ Yang X, Yu Y, Xu J, Shu H, Liu H, Wu Y, Zhang L, Yu Z, Fang M, Yu T, Wang Y. Clinical course and outcomes of critically ill patients with SARS-CoV-2 pneumonia in Wuhan, China: a single-centered, retrospective, observational study. The Lancet Respiratory Medicine. 2020 Feb 24.

${ }^{21}$ Chen N, Zhou M, Dong X, Qu J, Gong F, Han Y, Qiu Y, Wang J, Liu Y, Wei Y, Yu T. Epidemiological and clinical characteristics of 99 cases of 2019 novel coronavirus pneumonia in Wuhan, China: a descriptive study. The Lancet. 2020 Feb 15;395(10223):507-13.

${ }^{22}$ Ruan Q, Yang K, Wang W, Jiang L, Song J. Clinical predictors of mortality due to COVID-19 based on an analysis of data of 150 patients from Wuhan, China. Intensive care medicine. 2020 Mar 3:1-3.

${ }^{23}$ Wang T, Du Z, Zhu F, Cao Z, An Y, Gao Y, Jiang B. Comorbidities and multi-organ injuries in the treatment of COVID-19. The Lancet. 2020 Mar 9.

${ }^{24}$ Badawi A, Ryoo SG. Prevalence of comorbidities in the Middle East respiratory syndrome coronavirus (MERS-CoV): a systematic review and meta-analysis. International Journal of Infectious Diseases. 2016 Aug 1;49:129-33.

${ }^{25}$ Guan WJ, Ni ZY, Hu Y, Liang WH, Ou CQ, He JX, Liu L, Shan H, Lei CL, Hui DS, Du B. Clinical characteristics of coronavirus disease 2019 in China. New England Journal of Medicine. $2020 \mathrm{Feb} 28$.

${ }^{26}$ Zhang JJ, Dong X, Cao YY, Yuan YD, Yang YB, Yan YQ, Akdis CA, Gao YD. Clinical characteristics of 140 patients infected with SARS-CoV-2 in Wuhan, China. Allergy. $2020 \mathrm{Feb}$ 19.

${ }^{27}$ Blackburn R, Zhao H, Pebody R, Hayward A, Warren-Gash C. Laboratory-confirmed respiratory infections as predictors of hospital admission for myocardial infarction and stroke: time-series analysis of English data for 2004-2015. Clinical Infectious Diseases. 2018 Jun 18;67(1):8-17.

${ }^{28}$ Corrales-Medina VF, Musher DM, Shachkina S, Chirinos JA. Acute pneumonia and the cardiovascular system. The Lancet. 2013 Feb 9;381(9865):496-505.

${ }^{29}$ Timmer JR, Ottervanger JP, Thomas K, Hoorntje JC, de Boer MJ, Suryapranata H, Zijlstra F. Long-term, cause-specific mortality after myocardial infarction in diabetes. European heart journal. 2004 Jun 1;25(11):926-31.

${ }^{30}$ Udell JA, Zawi R, Bhatt DL, Keshtkar-Jahromi M, Gaughran F, Phrommintikul A, Ciszewski A, Vakili H, Hoffman EB, Farkouh ME, Cannon CP. Association between influenza vaccination and cardiovascular outcomes in high-risk patients: a meta-analysis. Jama. 2013 Oct 23;310(16):1711-20. 
${ }^{31}$ Zarychanski R, Stuart TL, Kumar A, Doucette S, Elliott L, Kettner J, Plummer F. Correlates of severe disease in patients with 2009 pandemic influenza (H1N1) virus infection. Cmaj. 2010 Feb 23;182(3):257-64.

${ }^{32}$ Li Q, Guan X, Wu P, Wang X, Zhou L, Tong Y, Ren R, Leung KS, Lau EH, Wong JY, Xing $\mathrm{X}$. Early transmission dynamics in Wuhan, China, of novel coronavirus-infected pneumonia. New England Journal of Medicine. 2020 Jan 29.

${ }^{33}$ Wan Y, Shang J, Graham R, Baric RS, Li F. Receptor recognition by the novel coronavirus from Wuhan: an analysis based on decade-long structural studies of SARS coronavirus. Journal of virology. 2020 Mar 17;94(7).

${ }^{34}$ Fang L, Karakiulakis G, Roth M. Are patients with hypertension and diabetes mellitus at increased risk for COVID-19 infection?. The Lancet. Respiratory Medicine. 2020 Mar 11. ${ }^{35}$ Mertz D, Kim TH, Johnstone J, Lam PP, Kuster SP, Fadel SA, Tran D, Fernandez E, Bhatnagar N, Loeb M. Populations at risk for severe or complicated influenza illness: systematic review and meta-analysis. Bmj. 2013 Aug 23;347:f5061.

${ }^{36}$ Al Soub H, Ibrahim AS, Al Maslamani M, Al-khal AL, Shaath S, Hamza NA. Epidemiology, risk factors, clinical features, and outcome of adult patients with severe pandemic A/H1N1/2009 influenza in Qatar: a retrospective study. Infectious Diseases in Clinical Practice. 2014 Nov 1;22(6):339-43.

${ }^{37}$ Huang C, Wang Y, Li X, Ren L, Zhao J, Hu Y, Zhang L, Fan G, Xu J, Gu X, Cheng Z. Clinical features of patients infected with 2019 novel coronavirus in Wuhan, China. The Lancet. 2020 Feb 15;395(10223):497-506.

${ }^{38} \mathrm{Wu} \mathrm{Z}$, McGoogan JM. Characteristics of and important lessons from the coronavirus disease 2019 (COVID-19) outbreak in China: summary of a report of 72314 cases from the Chinese Center for Disease Control and Prevention. Jama. 2020 Feb 24.

${ }^{39}$ Groom AV, Jim C, LaRoque M, Mason C, McLaughlin J, Neel L, Powell T, Weiser T, Bryan RT. Pandemic influenza preparedness and vulnerable populations in tribal communities. American Journal of Public Health. 2009 Oct;99(S2):S271-8.

${ }^{40}$ Hausmann LR, Ibrahim SA, Mehrotra A, Nsa W, Bratzler DW, Mor MK, Fine MJ. Racial and ethnic disparities in pneumonia treatment and mortality. Medical care. 2009 Sep;47(9):1009.

${ }^{41}$ Oliver MN, Stukenborg GJ, Wagner DP, Harrell Jr FE, Kilbridge KL, Lyman JA, Einbinder J, Connors Jr AF. Comorbid disease and the effect of race and ethnicity on in-hospital mortality from aspiration pneumonia. Journal of the National Medical Association. 2004 Nov;96(11):1462. ${ }^{42}$ Garrett TA. Pandemic economics: The 1918 influenza and its modern-day implications. Federal Reserve Bank of St. Louis Review. 2008 Mar 3;90(March/April 2008). ${ }^{43}$ Osterholm MT, Hedberg CW, Moore KA. The epidemiology of infectious diseases. GL M, Jr DRG, JE B, eds. Principles and Practice of Infectious Diseases. 5th ed ed. Philadelphia: Churchill Livingstone. 2000:161-3.

${ }^{44}$ Centers for Disease Control and Prevention. Compressed Mortality File on CDC WONDER. Centers for Disease Control and Prevention 2020. http://wonder.cdc.gov/mortSQL.html (accessed April 3, 2020).

${ }^{45} \mathrm{O}$ 'Brien KL, Santosham M. Potential impact of conjugate pneumococcal vaccines on pediatric pneumococcal diseases. American journal of epidemiology. 2004 Apr 1;159(7):634-44.

${ }^{46}$ Chowell G, Ayala A, Berisha V, Viboud C, Schumacher M. Risk factors for mortality among 2009 A/H1N1 influenza hospitalizations in Maricopa County, Arizona, April 2009 to March 2010. Computational and mathematical methods in medicine. 2012;2012. 
${ }^{47}$ Wilson N, Barnard LT, Summers JA, Shanks GD, Baker MG. Differential mortality rates by ethnicity in 3 influenza pandemics over a century, New Zealand. Emerging infectious diseases. 2012 Jan;18(1):71.

${ }^{48}$ Shrestha SS, Swerdlow DL, Borse RH, Prabhu VS, Finelli L, Atkins CY, Owusu-Edusei K, Bell B, Mead PS, Biggerstaff M, Brammer L. Estimating the burden of 2009 pandemic influenza A (H1N1) in the United States (April 2009-April 2010). Clinical Infectious Diseases. 2011 Jan 1;52(suppl_1):S75-82.

${ }^{49}$ Centers for Disease Control and Prevention2009 pandemic influenza A (H1N1) virus infections-Chicago, Illinois, April-July 2009. MMWR Morb Mortal Wkly Rep, 58 (2009), pp. 913-91

${ }^{50}$ Bishop JF, Murnane MP, Owen R. Australia's winter with the 2009 pandemic influenza A (H1N1) virus. New England Journal of Medicine. 2009 Dec 31;361(27):2591-4.

${ }^{51}$ La Ruche G, Tarantola A, Barboza P, Vaillant L, Gueguen J, Gastellu-Etchegorry M. The 2009 pandemic H1N1 influenza and indigenous populations of the Americas and the Pacific.

Eurosurveillance. 2009 Oct 22;14(42):19366.

${ }^{52}$ Baker MG, Wilson N, Huang QS, Paine S, Lopez L, Bandaranayake D, Tobias M, Mason K, Mackereth GF, Jacobs M, Thornley C. Pandemic influenza A (H1N1) v in New Zealand: the experience from April to August 2009. Eurosurveillance. 2009 Aug 27;14(34):19319.

${ }^{53}$ Centers for Disease Control and Prevention. Diabetes Report Card 2014. Atlanta, GA: Centers for Disease Control and Prevention, US Dept of Health and Human Services; 2015.

https://www.cdc.gov/diabetes/pdfs/library/diabetesreportcard2014.pdf. (Accessed April 3, 2020). ${ }^{54}$ Acton KJ, Ríos Burrows N, Moore K, Querec L, Geiss LS, Engelgau MM. Trends in diabetes prevalence among American Indian and Alaska native children, adolescents, and young adults. American Journal of Public Health. 2002 Sep;92(9):1485-90.

${ }^{55}$ Burrows NR, Geiss LS, Engelgau MM, Acton KJ. Prevalence of diabetes among Native Americans and Alaska Natives, 1990-1997: an increasing burden. Diabetes care. 2000 Dec 1;23(12):1786-90.

${ }^{56}$ Egede LE, Dagogo-Jack S. Epidemiology of type 2 diabetes: focus on ethnic minorities. Medical Clinics. 2005 Sep 1;89(5):949-75.

${ }^{57}$ Centers for Disease Control and Prevention. Chronic Kidney Disease Surveillance SystemUnited States. http://www.cdc.gov/ckd. (Accessed April 2, 2020)

${ }^{58}$ Suryaprasad A, Redd JT, Hancock K, Branch A, Steward-Clark E, Katz JM, Influenza Serology Working Group, Fry AM, Cheek JE, American Indian and Alaska Native Pandemic Influenza A (H1N1) Investigation Team. Severe acute respiratory infections caused by 2009 pandemic influenza A ( 11 N 1) among American Indians-southwestern United States, M ay 1-July 21, 2009. Influenza and other respiratory viruses. 2013 Nov;7(6):1361-9.

${ }^{59}$ Mau MK, Sinclair KI, Saito EP, Baumhofer KI, Kaholokula JK. Cardiometabolic health disparities in native Hawaiians and other Pacific Islanders. Epidemiologic reviews. 2009 Nov 1;31(1):113-29.

${ }^{60}$ Grandinetti A, Chang HK, Mau MK, Curb JD, Kinney EK, Sagum R, Arakaki RF. Prevalence of glucose intolerance among Native Hawaiians in two rural communities. Diabetes Care. 1998 Apr 1;21(4):549-54.

${ }^{61}$ Johnson DB, Oyama N, LeMarchand L, Wilkens L. Native Hawaiians mortality, morbidity, and lifestyle: comparing data from 1982, 1990, and 2000. Pac Health Dialog. 2004 Sep;11(2):120-30. 
${ }^{62}$ Auchincloss AH, Roux AV, Mujahid MS, Shen M, Bertoni AG, Carnethon MR. Neighborhood resources for physical activity and healthy foods and incidence of type 2 diabetes mellitus: the Multi-Ethnic study of Atherosclerosis. Archives of internal medicine. 2009 Oct 12;169(18):1698-704.

${ }^{63}$ Allison MA, Budoff MJ, Wong ND, Blumenthal RS, Schreiner PJ, Criqui MH. Prevalence of and risk factors for subclinical cardiovascular disease in selected US Hispanic ethnic groups: the Multi-Ethnic Study of Atherosclerosis. American journal of epidemiology. $2008 \mathrm{Apr}$ 15;167(8):962-9.

${ }^{64}$ Leigh JA, Alvarez M, Rodriguez CJ. Ethnic minorities and coronary heart disease: an update and future directions. Current atherosclerosis reports. $2016 \mathrm{Feb}$ 1;18(2):9.

${ }^{65}$ Mozaffarian D, Benjamin EJ, Go AS, Arnett DK, Blaha MJ, Cushman M, De Ferranti S, Després JP, Fullerton HJ, Howard VJ, Huffman MD. Executive summary: heart disease and stroke statistics - 2015 update: a report from the American Heart Association. circulation. 2015 Jan 27;131(4):434-41.

${ }^{66}$ Kurian AK, Cardarelli KM. Racial and ethnic differences in cardiovascular disease risk factors: a systematic review. Ethnicity and Disease. 2007 Dec 1;17(1):143.

${ }^{67}$ Mensah GA, Mokdad AH, Ford ES, Greenlund KJ, Croft JB. State of disparities in cardiovascular health in the United States. Circulation. 2005 Mar 15;111(10):1233-41.

${ }^{68}$ Centers for Disease Control and Prevention. Percentage of Patients with a Diagnosis of Hypertension. Centers for Disease Control and Prevention 2016.

https://nccd.cdc.gov/CKD/detail.aspx?Qnum=Q691\&Strat=Age,+Race/Ethnicity\#refreshPosition (accessed April 1, 2020).

${ }^{69}$ Bibbins-Domingo K, Pletcher MJ, Lin F, Vittinghoff E, Gardin JM, Arynchyn A, Lewis CE, Williams OD, Hulley SB. Racial differences in incident heart failure among young adults. New England Journal of Medicine. 2009 Mar 19;360(12):1179-90.

${ }^{70}$ Hertz RP, Unger AN, Cornell JA, Saunders E. Racial disparities in hypertension prevalence, awareness, and management. Archives of internal medicine. 2005 Oct 10;165(18):2098-104.

${ }^{71}$ Centers for Disease Control and Prevention. People Who Need to Take Extra Precautions. Centers for Disease Control and Prevention 2020. https://www.cdc.gov/coronavirus/2019ncov/need-extra-precautions/index.html (accessed April 8, 2020).

${ }^{72}$ Balabis J, Pobutsky AM. The burden of cardiovascular disease in Hawaii 2007. Hawaii State Department of Health; 2007.

${ }^{73}$ Centers for Disease Control and Prevention (CDC. Health status of American Indians compared with other racial/ethnic minority populations--selected states, 2001-2002. MMWR. Morbidity and mortality weekly report. 2003 Nov 28;52(47):1148.

${ }^{74}$ Novotny R, Davis J, Ross P, Wasnich R. Adiposity and blood pressure in a multiethnic population of women in Hawaii. Ethnicity \& health. 1998 Aug 1;3(3):167-73.

${ }^{75}$ Sundaram AA, Ayala C, Greenlund KJ, Keenan NL. Differences in the prevalence of selfreported risk factors for coronary heart disease among American women by race/ethnicity and age: Behavioral Risk Factor Surveillance System, 2001. American journal of preventive medicine. 2005 Dec 1;29(5):25-30.

${ }^{76}$ Grandinetti A, Chen R, Kaholokula JK, Yano K, Rodriguez BL, Chang HK, Curb JD. Relationship of blood pressure with degree of Hawaiian ancestry. Ethnicity \& disease. 2002;12(2):221-8.

${ }^{77}$ Moy KL, Sallis JF, David KJ. Health indicators of native Hawaiian and pacific islanders in the United States. Journal of community health. 2010 Feb 1;35(1):81-92. 
${ }^{78}$ Rodriguez CJ, Allison M, Daviglus ML, Isasi CR, Keller C, Leira EC, Palaniappan L, Piña IL, Ramirez SM, Rodriguez B, Sims M. Status of cardiovascular disease and stroke in Hispanics/Latinos in the United States: a science advisory from the American Heart Association. Circulation. 2014 Aug 12;130(7):593-625.

${ }^{79}$ Daviglus ML, Talavera GA, Avilés-Santa ML, Allison M, Cai J, Criqui MH, Gellman M, Giachello AL, Gouskova N, Kaplan RC, LaVange L. Prevalence of major cardiovascular risk factors and cardiovascular diseases among Hispanic/Latino individuals of diverse backgrounds in the United States. Jama. 2012 Nov 7;308(17):1775-84.

${ }^{80}$ Balfour Jr PC, Ruiz JM, Talavera GA, Allison MA, Rodriguez CJ. Cardiovascular disease in Hispanics/Latinos in the United States. Journal of Latina/o psychology. 2016 May;4(2):98.

${ }^{81}$ Sacco RL, Roberts JK, Boden-Albala B, Gu Q, Lin IF, Kargman DE, Berglund L, Hauser WA, Shea S, Paik MC. Race-ethnicity and determinants of carotid atherosclerosis in a multiethnic population: the Northern Manhattan Stroke Study. Stroke. 1997 May;28(5):929-35.

${ }^{82}$ Dawood FS, Kamimoto L, D'Mello TA, Reingold A, Gershman K, Meek J, Arnold KE, Farley M, Ryan P, Lynfield R, Morin C. Children with asthma hospitalized with seasonal or pandemic influenza, 2003-2009. Pediatrics. 2011 Jul 1;128(1):e27-32.

${ }^{83}$ Neuzil KM, Wright PF, Mitchel Jr EF, Griffin MR. The burden of influenza illness in children with asthma and other chronic medical conditions. The Journal of pediatrics. $2000 \mathrm{Dec}$ 1;137(6):856-64.

${ }^{84}$ Jain S, Kamimoto L, Bramley AM, Schmitz AM, Benoit SR, Louie J, Sugerman DE, Druckenmiller JK, Ritger KA, Chugh R, Jasuja S. Hospitalized patients with 2009 H1N1 influenza in the United States, April-June 2009. New England journal of medicine. 2009 Nov 12;361(20):1935-44.

${ }^{85}$ Centers for Disease Control and Prevention. 2018 National Health Interview Survey (NHIS Data): Table 4-1- Current Asthma Prevalence Percents by Age, United States: NHIS, 2018. Centers for Disease Control and Prevention 2019. https://www.cdc.gov/asthma/nhis/2018/table41.htm (accessed April 3, 2020).

${ }^{86}$ Akinbami OJ. The State of Childhood Asthma: United States, 1980-2005. US Department of Health and Human Services, Centers for Disease Control and Prevention, National Center for Health Statistics; 2006.

${ }^{87}$ Phelan JC, Link BG, Tehranifar P. Social conditions as fundamental causes of health inequalities: theory, evidence, and policy implications. Journal of health and social behavior. 2010 Mar;51(1_suppl):S28-40.

${ }^{88}$ Bell ML, Ebisu K. Environmental inequality in exposures to airborne particulate matter components in the United States. Environmental health perspectives. 2012 Dec;120(12):1699704.

${ }^{89}$ Cai Y, Zhang B, Ke W, Feng B, Lin H, Xiao J, Zeng W, Li X, Tao J, Yang Z, Ma W. Associations of short-term and long-term exposure to ambient air pollutants with hypertension: a systematic review and meta-analysis. Hypertension. $2016 \mathrm{Jul} ; 68(1): 62-70$.

${ }^{90}$ Penner LA, Hagiwara N. Racism and health. The Wiley Blackwell Encyclopedia of Health, Illness, Behavior, and Society. 2014 Jan 6:2037-41.

${ }^{91}$ Anderson KF. Diagnosing discrimination: Stress from perceived racism and the mental and physical health effects. Sociological Inquiry. 2013 Feb;83(1):55-81.

${ }_{92}$ Major B, Mendes WB, Dovidio JF. Intergroup relations and health disparities: A social psychological perspective. Health Psychology. 2013 May;32(5):514. 
${ }^{93}$ Mays VM, Cochran SD, Barnes NW. Race, race-based discrimination, and health outcomes among African Americans. Annu. Rev. Psychol.. 2007 Jan 10;58:201-25.

${ }^{94}$ Kuzawa CW, Sweet E. Epigenetics and the embodiment of race: developmental origins of US racial disparities in cardiovascular health. American Journal of Human Biology: The Official Journal of the Human Biology Association. 2009 Jan;21(1):2-15.

${ }^{95}$ Geronimus AT, Hicken M, Keene D, Bound J. "Weathering" and age patterns of allostatic load scores among blacks and whites in the United States. American journal of public health. 2006 May;96(5):826-33.

${ }^{96}$ Adegbembo AO, Tomar SL, Logan HL. Perception of racism explains the difference between Blacks' and Whites' level of healthcare trust. Ethnicity \& Disease. 2006 Jan 1;16(4):792-8.

${ }^{97}$ Hagiwara N, Penner LA, Gonzalez R, Eggly S, Dovidio JF, Gaertner SL, West T, Albrecht TL. Racial attitudes, physician-patient talk time ratio, and adherence in racially discordant medical interactions. Social Science \& Medicine. 2013 Jun 1;87:123-31.

${ }^{98}$ Penner LA, Dovidio JF, Hagiwara N, Foster T, Albrecht TL, Chapman RA, Eggly S. An analysis of race-related attitudes and beliefs in black cancer patients: Implications for health care disparities. Journal of health care for the poor and underserved. 2016;27(3):1503.

${ }_{99}$ Thompson HS, Valdimarsdottir HB, Winkel G, Jandorf L, Redd W. The Group-Based Medical Mistrust Scale: psychometric properties and association with breast cancer screening. Preventive medicine. 2004 Feb 1;38(2):209-18.

${ }^{100}$ Greenwald AG, Poehlman TA, Uhlmann EL, Banaji MR. Understanding and using the Implicit Association Test: III. Meta-analysis of predictive validity. Journal of personality and social psychology. 2009 Jul;97(1):17.

${ }^{101}$ Pendergrass DC, Raji MY. The Bitter Pill: Harvard and the Dark History of Birth Control: Magazine: The Harvard Crimson. Magazine | The Harvard Crimson 2017.

https://www.thecrimson.com/article/2017/9/28/the-bitter-pill/ (accessed April 2, 2020). ${ }_{102}$ Washington HA. Medical apartheid: The dark history of medical experimentation on Black Americans from colonial times to the present. Doubleday Books; 2006.

${ }^{103}$ Blendon RJ, Buhr T, Cassidy EF, Perez DJ, Hunt KA, Fleischfresser C, Benson JM, Herrmann MJ. Disparities in health: perspectives of a multi-ethnic, multi-racial America. Health Affairs. 2007 Sep;26(5):1437-47.

${ }^{104}$ Lee C, Ayers SL, Kronenfeld JJ. The association between perceived provider discrimination, health care utilization, and health status in racial and ethnic minorities. Ethnicity \& disease. 2009;19(3):330.

${ }^{105}$ Kaholokula JK, Iwane MK, Nacapoy AH. Effects of perceived racism and acculturation on hypertension in Native Hawaiians. Hawaii medical journal. 2010 May;69(5 suppl 2):11.

${ }^{106}$ Evans-Campbell T. Historical trauma in American Indian/Native Alaska communities: A multilevel framework for exploring impacts on individuals, families, and communities. Journal of interpersonal violence. 2008 Mar;23(3):316-38.

${ }^{107}$ Jones ML, Galliher RV. Daily racial microaggressions and ethnic identification among Native American young adults. Cultural Diversity and Ethnic Minority Psychology. 2015 Jan;21(1):1. ${ }^{108}$ Turner MA, Ross SL. Discrimination in Metropolitan Housing Markets: Phase 3-Native Americans.

${ }^{109}$ Byers LG. Depression, discrimination, trauma, and American Indian ethnic identity (Doctoral dissertation, ProQuest Information \& Learning).

${ }^{110}$ Liu DM, Alameda CK. Social determinants of health for Native Hawaiian children and adolescents. Hawaii medical journal. 2011 Nov;70(11 Suppl 2):9. 
${ }^{111}$ Whitbeck LB, Walls ML, Johnson KD, Morrisseau AD, McDougall CM. Depressed affect and historical loss among North American indigenous adolescents. American Indian and Alaska native mental health research (Online). 2009;16(3):16.

${ }_{112}$ Walls ML, Gonzalez J, Gladney T, Onello E. Unconscious biases: Racial microaggressions in American Indian health care. The Journal of the American Board of Family Medicine. 2015 Mar 1;28(2):231-9.

${ }^{113}$ Araújo Dawson B. Discrimination, stress, and acculturation among Dominican immigrant women. Hispanic Journal of Behavioral Sciences. 2009 Feb;31(1):96-111.

${ }^{114}$ Ryan AM, Gee GC, Laflamme DF. The association between self-reported discrimination, physical health and blood pressure: findings from African Americans, Black immigrants, and Latino immigrants in New Hampshire. Journal of health care for the poor and underserved. 2006;17(2):116-32.

${ }^{115}$ Schulz AJ, Williams DR, Israel BA, Lempert LB. Racial and spatial relations as fundamental determinants of health in Detroit. The Milbank Quarterly. 2002 Dec;80(4):677-707.

${ }^{116}$ Roux AV, Merkin SS, Arnett D, Chambless L, Massing M, Nieto FJ, Sorlie P, Szklo M, Tyroler HA, Watson RL. Neighborhood of residence and incidence of coronary heart disease. New England Journal of Medicine. 2001 Jul 12;345(2):99-106.

${ }^{117}$ Mujahid MS, Roux AV, Morenoff JD, Raghunathan TE, Cooper RS, Ni H, Shea S.

Neighborhood characteristics and hypertension. Epidemiology. 2008 Jul 1:590-8.

${ }^{118}$ Howel D, Moffatt S, Bush J, Dunn CE, Prince H. Public views on the links between air pollution and health in Northeast England. Environmental Research. 2003 Mar 1;91(3):163-71. ${ }^{119}$ Tucker MJ, Berg CJ, Callaghan WM, Hsia J. The Black-White disparity in pregnancy-related mortality from 5 conditions: differences in prevalence and case-fatality rates. American journal of public health. 2007 Feb;97(2):247-51.

${ }^{120}$ Gerber JS, Prasad PA, Localio AR, Fiks AG, Grundmeier RW, Bell LM, Wasserman RC, Rubin DM, Keren R, Zaoutis TE. Racial differences in antibiotic prescribing by primary care pediatricians. Pediatrics. 2013 Apr 1;131(4):677-84.

${ }^{121}$ Squitieri L, Reichert H, Kim HM, Steggerda J, Chung KC. Patterns of surgical care and health disparities of treating pediatric finger amputation injuries in the United States. Journal of the American College of Surgeons. 2011 Oct 1;213(4):475-85.

${ }^{122}$ Durazzo TS, Frencher S, Gusberg R. Influence of race on the management of lower extremity ischemia: revascularization vs amputation. JAMA surgery. 2013 Jul 1;148(7):617-23.

${ }^{123}$ Fine JM, Fine MJ, Galusha D, Petrillo M, Meehan TP. Patient and hospital characteristics associated with recommended processes of care for elderly patients hospitalized with pneumonia: results from the medicare quality indicator system pneumonia module. Archives of internal medicine. 2002 Apr 8;162(7):827-33.

${ }^{124}$ Blair IV, Steiner JF, Hanratty R, Price DW, Fairclough DL, Daugherty SL, Bronsert M, Magid DJ, Havranek EP. An investigation of associations between clinicians' ethnic or racial bias and hypertension treatment, medication adherence and blood pressure control. Journal of general internal medicine. 2014 Jul 1;29(7):987-95.

${ }^{125}$ Green AR, Carney DR, Pallin DJ, Ngo LH, Raymond KL, Iezzoni LI, Banaji MR. Implicit bias among physicians and its prediction of thrombolysis decisions for black and white patients. Journal of general internal medicine. 2007 Sep 1;22(9):1231-8.

${ }^{126}$ FitzGerald C, Hurst S. Implicit bias in healthcare professionals: a systematic review. BMC medical ethics. 2017 Dec;18(1):19. 
${ }^{127}$ Dehon E, Weiss N, Jones J, Faulconer W, Hinton E, Sterling S. A systematic review of the impact of physician implicit racial bias on clinical decision making. Academic Emergency Medicine. 2017 Aug;24(8):895-904.

${ }^{128}$ Oliver MN, Wells KM, Joy-Gaba JA, Hawkins CB, Nosek BA. Do physicians' implicit views of African Americans affect clinical decision making?. The Journal of the American Board of Family Medicine. 2014 Mar 1;27(2):177-88.

${ }^{129}$ Sabin JA, Rivara FP, Greenwald AG. Physician implicit attitudes and stereotypes about race and quality of medical care. Medical care. 2008 Jul 1:678-85.

${ }^{130}$ Dovidio JF, Penner LA, Albrecht TL, Norton WE, Gaertner SL, Shelton JN. Disparities and distrust: the implications of psychological processes for understanding racial disparities in health and health care. Social science \& medicine. 2008 Aug 1;67(3):478-86.

${ }^{131}$ Kalev A, Dobbin F, Kelly E. Best practices or best guesses? Assessing the efficacy of corporate affirmative action and diversity policies. American sociological review. 2006 Aug;71(4):589-617.

${ }^{132}$ Saha S, Beach MC, Cooper LA. Patient centeredness, cultural competence and healthcare quality. Journal of the National Medical Association. 2008 Nov 1;100(11):1275-85.

${ }^{133}$ Monteith MJ, Mark AY, Ashburn-Nardo L. The self-regulation of prejudice: Toward understanding its lived character. Group Processes \& Intergroup Relations. 2010 Mar;13(2):183200.

${ }^{134}$ Kahn JR, Pearlin LI. Financial strain over the life course and health among older adults. Journal of health and social behavior. 2006 Mar;47(1):17-31.

${ }^{135} \mathrm{McDonough}$ P, Berglund P. Histories of poverty and self-rated health trajectories. Journal of Health and Social Behavior. 2003 Jun 1:198-214.

${ }^{136}$ Braveman PA, Cubbin C, Egerter S, Williams DR, Pamuk E. Socioeconomic disparities in health in the United States: what the patterns tell us. American journal of public health. 2010 Apr;100(S1):S186-96.

${ }^{137}$ Minkler M, Fuller-Thomson E, Guralnik JM. Gradient of disability across the socioeconomic spectrum in the United States. New England Journal of Medicine. 2006 Aug 17;355(7):695-703. 1382018 National Healthcare Quality and Disparities Report. Agency for Healthcare Research and Quality 2019. https://www.ahrq.gov/research/findings/nhqrdr/nhqdr18/index.html (accessed April 1, 2020).

${ }^{139}$ Kaufman BG, Thomas SR, Randolph RK, Perry JR, Thompson KW, Holmes GM, Pink GH. The rising rate of rural hospital closures. The Journal of Rural Health. 2016 Jan;32(1):35-43. ${ }^{140}$ LaVeist TA, Rolley NC, Diala C. Prevalence and patterns of discrimination among US health care consumers. International Journal of Health Services. 2003 Apr;33(2):331-44.

${ }^{141}$ Pucher J, Renne JL. Socioeconomics of urban travel: evidence from the 2001 NHTS. Transportation Quarterly. 2003 Jun 1;57(3):49-77.

${ }^{142}$ Blumenshine P, Reingold A, Egerter S, Mockenhaupt R, Braveman P, Marks J. Pandemic influenza planning in the United States from a health disparities perspective. Emerging infectious diseases. 2008 May;14(5):709.

${ }^{143}$ U.S. Bureau of Labor Statistics. Higher wage workers more likely than lower wage workers to have paid leave benefits in 2018. US Bureau of Labor Statistics 2018.

https://www.bls.gov/opub/ted/2018/higher-wage-workers-more-likely-than-lower-wage-workersto-have-paid-leave-benefits-in-2018.htm (accessed April 3, 2020)

${ }^{144}$ Smith K, Schaefer AP. Rural workers have less access to paid sick days. Carsey Institute Issue Brief No. 32. 
${ }^{145}$ Rothstein MA, Talbott MK. Encouraging compliance with quarantine: a proposal to provide job security and income replacement. American journal of public health. 2007 Apr;97(Supplement_1):S49-56.

${ }^{146}$ Barnett JC, Vornovitsky MS. Health insurance coverage in the United States: 2015.

Washington, DC: US Government Printing Office; 2016 Sep 13.

${ }^{147}$ Hadler JL, Yousey-Hindes K, Pérez A, Anderson EJ, Bargsten M, Bohm SR, Hill M, Hogan B, Laidler M, Lindegren ML, Lung KL. Influenza-related hospitalizations and poverty levelsUnited States, 2010-2012. Morbidity and Mortality Weekly Report. 2016 Feb 12;65(5):101-5.

${ }^{148}$ Kumar S, Piper K, Galloway DD, Hadler JL, Grefenstette JJ. Is population structure sufficient to generate area-level inequalities in influenza rates? An examination using agent-based models. BMC Public Health. 2015 Dec 1;15(1):947.

${ }^{149}$ Chen J, Chu S, Chungbaek Y, Khan M, Kuhlman C, Marathe A, Mortveit H, Vullikanti A, Xie D. Effect of modelling slum populations on influenza spread in Delhi. BMJ open. 2016 Sep 1;6(9):e011699.

${ }^{150}$ Adler NE, Newman K. Socioeconomic disparities in health: pathways and policies. Health affairs. 2002 Mar;21(2):60-76.

${ }^{151}$ Link BG, Phelan J. Social conditions as fundamental causes of disease. Journal of health and social behavior. 1995 Jan 1:80-94.

${ }^{152}$ Rodriguez CJ, Sciacca RR, Diez-Roux AV, Boden-Albala B, Sacco RL, Homma S, DiTullio MR. Relation between socioeconomic status, race-ethnicity, and left ventricular mass: the Northern Manhattan Study. Hypertension. 2004 Apr 1;43(4):775-9.

${ }^{153}$ Tienda M, Mitchell F, National Research Council (US) Panel on Hispanics in the United States. Multiple origins, uncertain destinies: Hispanics and the American future. National Academies Press (US); 2006.

${ }^{154}$ Williams DR. Race, socioeconomic status, and health the added effects of racism and discrimination. 1999.

${ }^{155}$ Census Bureau. Statistical abstract of the United States. Government Printing Office; 2009.

${ }^{156}$ Williams DR, Jackson PB. Social sources of racial disparities in health. Health affairs. 2005 Mar;24(2):325-34.

${ }^{157}$ LaVeist TA, Thorpe RJ, Galarraga JE, Bower KM, Gary-Webb TL. Environmental and socioeconomic factors as contributors to racial disparities in diabetes prevalence. Journal of general internal medicine. 2009 Oct 1;24(10):1144.

${ }^{158}$ Louie GH, Ward MM. Socioeconomic and ethnic differences in disease burden and disparities in physical function in older adults. American journal of public health. 2011 Jul;101(7):1322-9.

${ }^{159}$ Crimmins EM, Kim JK, Alley DE, Karlamangla A, Seeman T. Hispanic paradox in biological risk profiles. American journal of public health. $2007 \mathrm{Jul} ; 97(7): 1305-10$.

${ }^{160}$ Nelson A. Unequal treatment: confronting racial and ethnic disparities in health care. Journal of the National Medical Association. 2002 Aug;94(8):666.

${ }^{161}$ Williams DR, Mohammed SA, Leavell J, Collins C. Race, socioeconomic status and health: Complexities, ongoing challenges and research opportunities. Annals of the New York Academy of Sciences. 2010 Feb;11(86):69.

${ }^{162}$ Lantz PM, Mujahid M, Schwartz K, Janz NK, Fagerlin A, Salem B, Liu L, Deapen D, Katz SJ. The influence of race, ethnicity, and individual socioeconomic factors on breast cancer stage at diagnosis. American journal of public health. 2006 Dec;96(12):2173-8. 
${ }^{163}$ Penner LA, Blair IV, Albrecht TL, Dovidio JF. Reducing racial health care disparities: a social psychological analysis. Policy insights from the behavioral and brain sciences. 2014 Oct;1(1):204-12.

${ }^{164}$ White K, Haas JS, Williams DR. Elucidating the role of place in health care disparities: the example of racial/ethnic residential segregation. Health services research. 2012 Jun;47(3pt2):1278-99.

${ }^{165}$ Eschbach K, Ostir GV, Patel KV, Markides KS, Goodwin JS. Neighborhood context and mortality among older Mexican Americans: is there a barrio advantage? American journal of public health. 2004 Oct;94(10):1807-12.

${ }^{166}$ Marrone S. Understanding barriers to health care: a review of disparities in health care services among indigenous populations. International Journal of Circumpolar Health. 2007 Jul 1;66(3):188-98.

${ }^{167}$ Fong M, Braun KL, Tsark JU. Improving Native Hawaiian health through community-based participatory research. Californian journal of health promotion. 2003 Dec 31;1(SI):136-48. ${ }^{168}$ Quinn SC, Kumar S, Freimuth VS, Musa D, Casteneda-Angarita N, Kidwell K. Racial disparities in exposure, susceptibility, and access to health care in the US H1N1 influenza pandemic. American journal of public health. 2011 Feb;101(2):285-93.

${ }^{169}$ Link BG. Epidemiological sociology and the social shaping of population health. Journal of health and social behavior. 2008 Dec;49(4):367-84.

${ }^{170}$ Iezzoni LI, Killeen MB, O'Day BL. Rural residents with disabilities confront substantial barriers to obtaining primary care. Health services research. 2006 Aug;41(4p1):1258-75. ${ }^{171}$ Davidsson N, Södergård B. Access to healthcare among people with physical disabilities in rural Louisiana. Social work in public health. 2016 Apr 15;31(3):188-95.

${ }^{172}$ Corrigan P, Thompson V, Lambert D, Sangster Y, Noel JG, Campbell J. Perceptions of discrimination among persons with serious mental illness. Psychiatric Services. 2003 Aug;54(8):1105-10.

${ }^{173}$ Ali A, Scior K, Ratti V, Strydom A, King M, Hassiotis A. Discrimination and other barriers to accessing health care: perspectives of patients with mild and moderate intellectual disability and their carers. PloS one. 2013;8(8).

${ }^{174}$ Drainoni ML, Lee-Hood E, Tobias C, Bachman SS, Andrew J, Maisels L. Cross-disability experiences of barriers to health-care access: consumer perspectives. Journal of Disability Policy Studies. 2006 Sep;17(2):101-15.

${ }^{175}$ DeJong G, Palsbo SE, Beatty PW. 1. The organization and financing of health services for persons with disabilities. The Milbank Quarterly. 2002 Jun;80(2):261-301.

${ }^{176}$ Plantinga L, Johansen KL, Schillinger D, Powe NR. Lower socioeconomic status and disability among US adults with chronic kidney disease, 1999-2008. Preventing chronic disease. 2012;9.

${ }^{177}$ Kinne S, Patrick DL, Doyle DL. Prevalence of secondary conditions among people with disabilities. American Journal of Public Health. 2004 Mar;94(3):443-5.

${ }^{178}$ Kattari SK, Walls NE, Whitfield DL, Langenderfer-Magruder L. Racial and ethnic differences in experiences of discrimination in accessing health services among transgender people in the United States. International Journal of Transgenderism. 2015 Apr 3;16(2):68-79.

${ }^{179}$ Gates, G.J., \& Newport, F. (2012). Special report: 3.4\% of US adults identify as LGBT. http://www.gallup.com/poll/158066/special-report-adults-identify-lgbt.aspx. (Accessed April 3, 2020) 
${ }^{180}$ Fredriksen-Goldsen KI, Kim HJ, Barkan SE, Muraco A, Hoy-Ellis CP. Health disparities among lesbian, gay, and bisexual older adults: Results from a population-based study. American journal of public health. 2013 Oct;103(10):1802-9.

${ }^{181}$ Roberts TK, Fantz CR. Barriers to quality health care for the transgender population. Clinical Biochemistry. 2014 Jul 1;47(10-11):983-7.

${ }^{182}$ Macapagal K, Bhatia R, Greene GJ. Differences in healthcare access, use, and experiences within a community sample of racially diverse lesbian, gay, bisexual, transgender, and questioning emerging adults. LGBT health. 2016 Dec 1;3(6):434-42.

${ }^{183}$ Krehely, J. (2009). How to close the LGBT health disparities gap. Center for American Progress, 1(9).

${ }^{184}$ Benfer EA, Wiley LF. Health Justice Strategies To Combat COVID-19: Protecting Vulnerable Communities During A Pandemic. Health Affairs Blog 2020.

https://www.healthaffairs.org/do/10.1377/hblog20200319.757883/full/ (accessed April 3, 2020). 